\title{
Democratic local governance in the Southern African development community region: Some emerging issues and challenges
}

Commonwealth Journal of Local Governance

Special Issue March 2010:

Commonwealth Local Government Conference

Freeport, Bahamas, May 2009

http:/lepress.lib.uts.edu.au/ojs/index.php/cjlg

\section{Bornwell Chikulo}

NorthWest University, South Africa

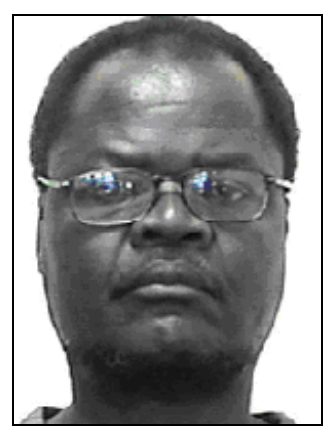

\section{Introduction}

Recent reforms have been transforming the structure of local governance in the Southern Africa Development Community (SADC) region. Since the 1990s, a critical objective of governance reform has been the strengthening of local government by the decentralization of powers, resources and responsibilities to local authorities and other locally administered bodies. These reforms have been labelled 'democratic decentralization' by scholars (Ribot, 2004; Olowu \& Wunsch, 2004). Democratic decentralization refers to initiatives which entail the transfer of significant authority, responsibility for services, fiscal and human resources to local governance. The objective of the reforms was to capacitate local governance structures, as well as to increase the capacity and productivity of the public sector in general (Hope \& Chikulo, 2000). Efforts to improve institutional effectiveness, accountability and service delivery at the local level thus have been a major focus throughout the region.

The Declaration and Treaty establishing the Southern African Development Community (SADC) was signed on July 17, 1992 in Windhoek, Namibia, replacing the Southern African Development Coordination Conference (SADCC), which had been in existence 
since 1980. South Africa joined SADC in 1994 followed by Mauritius in 1995, the Democratic Republic of Congo (DRC) in 1997 and Seychelles in 1997. ${ }^{1}$ The issue of local government and municipalisation lies at the core of the SADC vision. To this end, almost all governments in the region have committed themselves to the establishment of decentralized democratic local governance. Consequently, over the past decade most governments have chosen to devolve, to varying degrees, authority, responsibility, resources and autonomy to elected local authorities.

This paper examines and reviews the issues and challenges that governments in the SADC region are facing in their efforts to establish democratic, developmental local governance.

\section{Emerging key issues and challenges}

As indicated above, legal, policy and institutional frameworks have been put in place to establish and democratise local governments with the objective of deepening democracy, and improving service delivery, local development and management. The reform process therefore holds considerable promise with specific regard to: enhancing transparency and accountability; facilitating citizen participation; facilitating effective and efficient public service delivery; and integrating society with the state. However, despite the significant progress achieved since the local governance reforms were set in motion, there are still some significant outstanding contentious issues that need to be resolved before the effective implementation of the reform programmes can be finalised. The key issues are as follows:

- Lack of political will or authority

- Absence of a holistic development framework

- Ineffective institutionalisation of local participation committees

- Management capacity constraints and deficits

- Fiscal crisis

- Role of traditional authorities

- Weak links civil society organisations

- Undemocratic behaviour by ruling regimes.

${ }^{1}$ SADC member states are now: Angola, Botswana, Democratic Republic of Congo, Lesotho, Malawi, Mauritius, Mozambique, Namibia, Seychelles, South Africa, Swaziland, Tanzania, Zambia and Zimbabwe. 


\section{Resistance to political will}

The reforms in the SADC region seem to reflect considerable 'political will' to transfer authority and responsibilities to lower tiers of government, and significant progress has been made. However, the main problems which are acknowledged in most of the studies is foot-dragging or a lack of cooperation from central ministries, and reluctance to transfer sufficient functions and powers to local governance structures, since doing so would greatly reduce their own power (Olowu, 2001; Olowu and Wunsch, 2004; Chinsinga, 2008; Ashley,et al, 2008). In the case of Mozambique, it has been pointed out that the emerging picture is one of "continued commitment to centralism" (Ashley et $\mathrm{Al}$, 2008:6). In some countries central ministries dominate local authorities, and in others, cooperation between sectoral ministries and local government is lacking (UN, 2004; World Bank, 2007). Another development in countries such as Zambia and Zimbabwe is the manoeuvre by some key sectoral ministries to re-centralise activities by setting up their own parallel sector specific coordination boards at the district level (Stewart, 1994). Lack of political authority to overcome such obstruction results in misdirected or incomplete implementation of decentralisation policies, which may ultimately undermine efforts to establish sustainable and inclusive local authorities. Fledgling local authorities find themselves competing with centres of authority at district level.

\section{Development planning and management}

There is a lack of holistic, integrated planning and management at district level. The common structure for development planning in most countries is the District Development Committee (DDC), chaired by central government's district representative, with membership consisting of all the heads of central government departments and parastatal bodies, MPs, plus representatives of political parties, local authorities, business and community based organizations. These committees are thus dominated by central government appointees (Makumbe, 1999; Chishinga, 2008) and chaired not by an elected local authority official, but a political appointee who is the alter ego of the President, called a District Administrator (DA). The role of DAs has tended to be controversial: as political appointees, they often focus mostly on strengthening the ruling party structures at district level, rather than coordinating socio-economic development programmes.

Effective integrated planning and management is therefore undermined by the absence of an effective coordinating mechanism under the direct control of local authorities. The 
local authorities have no legal administrative authority over central government line departments. The deconcentrated sector ministries which provide services within a local council's area of jurisdiction report and account upwards direct to their parent ministries. Thus they remain primarily answerable to their ministerial chain of command. Furthermore, the development committees' relationships to other community and local structures is not well defined. Consequently, the residents are denied an effective voice.

Although South Africa has different arrangements, and legally a stronger role for local government, observers such as Bardill and Tapscott (2000) have nonetheless identified weaknesses in intergovernmental relations, with poor coordination among various levels and departments of government. Furthermore, as Ashley et al have aptly observed, in spite of commitment to decentralization, political and institutional power still resides at the centre: "The resources and responsibilities vested in the local sphere of government continue to set largely by other spheres of government, particularly line departments at provincial levels, such as Water Affairs, Public Works and Housing” (Ashley et al, 2008:8).

According to the Municipal Systems Act 2000, South African municipalities must prepare Integrated Development Plans (IDPs) for their areas, and extensive community participation in both the content of an IDP and the process by which it is drafted is compulsory. In short, it is supposed to be a ‘bottom-up’ participatory process. However, IDPs must be aligned with provincial and national government plans, and in most instances this means that development projects are only approved when they fit into central government plans and vision (Oluwu \& Wunsch, 2004). As a result, planning still tends to be top-down and, due to lack of skills and resources in municipalities, often is ‘consultant-driven' with only token community participation.

Throughout the region, the existence of parallel national and provincial government departments working through their district offices complicates development planning and service delivery (Ashley et al, 2008), with the end result that service delivery and development projects at district level are determined through a top-down process. This impairs effective and efficient public service delivery that is responsive to local needs, and undermines the autonomy and authority of local governance. Moreover, the growth in development project aid channeled directly to communities, bypassing local 
government structures, not only exacerbates the problem of coordinating and monitoring local development activities but also undermines community-local government linkages. The challenge is again one of local versus national department development interests, and the problem of being able to account for, and coordinate development projects sponsored by different departments and donors.

\section{Ineffective participatory committees}

At the sub- district and local level, in all the countries, a network of committees has been created to serve as a mechanism for representation, participation and accountability in development management and planning. The introduction of such committees - district, settlement, ward or village development committees - is an important innovation in the effort to enhance participatory local democracy. It is therefore an important component of local governance reform in the region. However, in the majority of countries, these committee networks have not been effectively institutionalized. In South Africa, for example, the principle of participation is entrenched in the constitution which requires local government to "encourage the involvement of communities and community organizations in matters of local government" (RSA, 1996:81). Furthermore, the Municipal Systems Act 2000 obligates local government to establish mechanisms to enable communities to participate in ward committees. However, these committees in general have not been effective channels and there is a lack of connectivity between communities and municipalities as a result (de Visser, 2009; Christmas \& de Visser, 2009; Pycroft, 2000a). As Atkinson (2001) has observed, although wards are government created platforms for community engagement with local government, communities in South Africa still elect to take their grievances to the streets. Evidence in other countries also suggests that for the most part, the network of development committees is not very active, and in some cases they only exist on paper (Chinsinga, 2008; Chikulo, 2009). As a result the challenge is the limited level of public participation in development management.

\section{Management capacity}

Management capacity deficit is a major hindrance to effective local governance. There is insufficient human resources capacity to cope with the multiplicity of mandates which have to be carried out more or less simultaneously by the decentralised democratic local governance structures. With the exception of Zimbabwe, which until the recent political 
and economic melt-down, was said to possess a decent quality of municipal government staff, the scarcity of qualified staff - especially professional and technical staff - has been a major constraint for most of the local authorities in the region (Chikulo, 2004; Sperfeld, 2005). The result is a barrier to effective and efficient development management.

Lack of capacity has been cited in Malawi and Mozambique by Kithakye (1997) and.Sperfeld (2008). In South Africa, the problem of the shortage of skilled manpower is widespread, and in some instances was exacerbated by the exodus of experienced municipal managers from council employment (Pycroft, 2000b). De Visser and Christmas 2009 also argue that lack of capacity has been exacerbated by appointments based on political patronage rather than skills and expertise. Pycroft (2002) has noted that while municipal capacity tends to be concentrated within metropolitan municipalities, administrative capacity deficit is prevalent at district level.

The problem is exacerbated in rural municipalities by their remoteness from urban centres. In South Africa, it is difficult to attract a high calibre of municipal officers to these areas where working conditions may be difficult. Rural local authorities thus lack the organizational, technical and administrative capabilities to fulfil their mandate. Consequently, as Harrison points out: "many local authorities in South Africa are so weak institutionally that they cannot perform even the most basic functions of management, service delivery, a sophisticated level of integrated and coordinated planning remains a long way off” (Harrison 2001:191).

Under such circumstances, councils have struggled to fulfil their responsibilities in terms of the constitution and the relevant local government legislation. Administrative capacity deficits should therefore be seen as a common, ongoing problem for most local authorities in the region. In recent years, recognition that decentralisation is often been impeded by a lack of capacity has resulted in emphasis on local government capacitybuilding efforts.

\section{Fiscal resources}

Another fundamental problem which has afflicted local governance in the region over the past decades has been the gap between financial resources and municipal expenditure needs, coupled with inadequate financial management systems. The taxing powers of 
local authorities are not wide enough, and the yield from existing sources is in most cases inadequate, to meet their expanding expenditures for both development and recurrent services. Consequently, dependency on central government grants is a common feature of local government in the region. Even South Africa, which is characterized by a high degree of fiscal decentralization, and where local government is entitled to an equitable share of nation revenue, the majority of local authorities are highly dependent on central government.

There are a number of issues relating to the financial crisis most local authorities are facing. The first is that the ability of local authorities to derive adequate revenue from their own local sources, such as property taxes and service charges, is constrained by central government restrictions imposed for fear of eroding political support among the urban populace (such as was the case in Zambia and Zimbabwe (Chikulo, 2006 ; Maipose, 2003; Sharma, 2003). Secondly, most local authorities in rural areas lack the capacity to generate enough revenue to meet their mandates: they have a concentration of poor residents and limited commercial or industrial activity which means that their tax base, whether from individual households rates, service payments or levies on commercial activity is minimal. Third, local authorities, especially in South Africa, continue to face a 'culture of non-payment' of charges for basic services, mainly by township dwellers, a habit which has origins the apartheid legacy. This has resulted in massive accumulated deficits from non-payment of such services as refuse collection and water supplies (Pycroft, 2002; Nel \& Binns, 2001). Fourth, local governments suffer from increasing 'unfunded mandates' - although additional responsibilities have been devolved to local governance, appropriate levels of funding have not followed (Nel \& Binns, 2002; Smith, 2001; Chinsinga, 2008). Finally, poor financial management in local authorities, such as inadequate financial and budgetary management systems, and poor record-keeping, often results in the mismanagement of scarce financial resources. The above financial constraints raise the issue of fiscal autonomy or sovereignty, which lies at the heart of the issue of local governance responsiveness and effective service delivery.

Most local authorities have limited autonomy with respect to revenue and expenditures, as most grants from central government are conditional and earmarked for specific projects. Financial dependence on central government also tends to limit the scope for 
establishing independent positions on development policy issues. Thus, until such time as local authorities become capable of raising significant amounts of their own revenue - as envisaged in most of the decentralisation policies of the governments in the region - the mentality of 'he who pays the piper, calls the tune' is bound to continue. In other words, service delivery and development will continue to be 'supply driven' instead of 'demand driven', as most local governments in the region remain upwardly accountable to central ministries. Thus the financial crisis faced by most local governments is a serious impediment to effective public service delivery and good governance. Without financial sustainability, local governments are unable to govern effectively or provide services to their communities, and their developmental capacity and autonomy are undermined.

\section{Traditional leadership and local governance}

A recurring issue in decentralised local governance reform is the status and role of traditional leaders. Reconciling traditional authorities and local government has become a major contentious policy and constitutional issue in Mozambique, Namibia, South Africa and Zimbabwe (Ndiyepa, 2001; Reddy \& Naidu, 2007). During the colonial era, traditional authorities were assigned powers either in competition with or directly over elected local authorities. In the immediate post-independence era, the democratisation of local government undermined the political control of traditional authorities, with traditional leaders resisting the loss of previous considerable powers to control access to resources (land, water, livelihoods), to arbitration mechanisms, and to services such as education and health. Obviously, traditional authorities also objected to the new municipal boundaries which cut across rural districts and tribal land.

An issue that is still under debate is how traditional authorities should participate in local governance. In Botswana, South Africa and Swaziland traditional authorities are recognised as a fourth level of local government. In these countries, the devolution of political and administrative powers may have somewhat re-invigorated traditional authorities and given them a new lease of life (Ntsebeza, 1999). In Botswana, for instance, chiefs have many responsibilities including law and order, administration of justice and serving as spokesperson for their tribes. The chief, who is also the head of the tribal administration, is by virtue of his position an ex officio member of the district council. Even in those instances where no tribal authorities are officially recognised, traditional leaders are represented on local authorities as a means for institutionalising 
legitimate local governance. Traditional leaders have therefore demanded an active role in democratically elected institutions, especially at the local government level (Jones, 2000).

In recent years, however, chiefs in Namibia, Mozambique, Zambia, Zimbabwe and South Africa have increasingly sought to reassert their authority (Ribot, 2002). They feel that their authority has been undermined by the transfer of control over allocation of resources such as land, and other legitimate powers to local authorities. Consequently, they are re-emerging as a political force against what they perceive to be a diminution of their role, which new forms of local governance have reinforced and institutionalised. In South Africa, the institutional of traditional leadership is recognised in the constitution, although their roles and functions are not adequately clarified, resulting in tensions between chiefs and elected councillors. Despite provisions in the Municipal Structures Amendment Act that allow traditional leaders to participate in council meetings, in an $e x$ officio capacity, traditional authorities are still at loggerheads with new councils. The challenge posed by the tension between traditional authorities and local governments remain pervasive in most Southern African countries and may negate effective local governance. The challenge is how to draw on the strengths of traditional authorities while reinforcing and legitimating democratic local government.

\section{Links with civil society}

Non-government organisations (NGOs) and community-based groups (CBOs) are normally seen to be pivotal in the provision of participatory and responsive development. It is argued that NGOs and CBOs should work closely with local government and where necessary compete with them or replace them. Thus NGOs and CBOs are expected to play a critical role in democratic decentralisation by providing services, lobbying government to provide greater services, and making people aware of their rights. However, it has also been observed that NGOs and CBOs in some instances may have a negative impact on local governance and hence on the foundations for effective democratic decentralisation. Collier (1996) has elaborated on instances where NGOs tried to undermine the development of local governments that are seen as a threat to their powerful position in the community (Smith, 2001).

However, in the Southern African region, the participation of NGOs and civil society in local governance remains minimal. Despite the legal mandate in South Africa for civil 
society participation in the local governance process, civil society engagement with local government is often viewed to be ineffective, inconsistent or lacking altogether. The civil society sector, including NGOs and CBOs, still find it difficult to engage and partner with local government in promoting development. Consequently, many CBOs are unable to influence local governance in a manner that would effectively benefit their communities. It has also been generally observed that local authorities have been reluctant to embrace and engage civil society, NGOs and CBOs and to give effect to principles of participatory governance. This robs local governments of valuable opportunities which could reinvigorate their development.

\section{Undemocratic behavior by ruling regimes}

In recent years, some regimes in the region have deliberately undermined the effectiveness of local governance in order to pursue their party political agenda. In Zimbabwe, the ZANU-PF regime began to undermine what had been strong and efficient urban municipalities, after the previously weak opposition movement, the Movement for Democratic Change (MDC), became reinvigorated into a strong opposition party and made major in-roads. The MDC not only increasing its representation in parliament but also won control of most urban councils after 2001. Similarly, in Malawi since the tenure of councillors who were elected during the first local elections held in November 2000 expired in May 2005, no elections have been held to date. Consequently, there are no local government councillors to represent the residents. The indefinite postponement of local government elections is politically motivated and has been mainly attributed to the ruling party's (Democratic Progressive Party) fear of losing in the local polls (Chinsinga, 2008). In Lesotho too, following the 1993 general elections that were won by the Basotho Congress party (BCP), parliament subsequently passed the Local Government Act No.6 1997, but the Act did not come into operation due to political factors until 2005, when the local government councils were finally elected (Sperfeld, 2008).

\section{Conclusion}

Local governance in the SADC region has been given a pivotal and distinctive role in the promotion of sustainable socio-economic development and deepening democracy at the sub-national level. This recognition of the developmental role of local government has given local authorities a new dynamic as instruments of sustainable development and effective service delivery. However, although significant progress has been made in 
establishing the institutional structure and policy framework to facilitate and anchor effective delivery of public services and socio-economic development, key issues and challenges persist that are unlikely to be resolved in the near future.

\section{References:}

AGF-V 2002, Local Government and Poverty Reduction: Zimbabwe Country Paper. Prepared for the Fifth Africa Governance Forum: AGF-V Maputo, Mozambique, 22-25 May.

Ashley, C. et al 2008, The Politics of Decentralization in Southern Africa, Washington, DC: Future Agricultures Consortium, Policy Process Briefing for WDR.

Atkinson, D. 2007, 'Taking to the Streets: Has Developmental Local Government Failed in South Africa?', in S. Buhlungu, J. Daniel, R. Southall and J. Lutchmann, eds. State of the Nation South Africa 2007, CapeTown: HSRC.

Bardill, J. E. 2000. 'Towards a Culture of Good Governance', Public Administration and Development, vol. 20, no. 2, pp.103-118.

Blair, H. 1997, Spreading Power to the Periphery: A USAID assessment of democratic local governance. Rome: Food and Agriculture Organization of the United Nations.

Chikulo, B. C. 2009, 'Local Governance Reforms in Zambia: A Review', Commonwealth Journal of Local Governance, vol 2 (January), pp. 98-106.

Chikulo, B. C. 2006, 'Local Governance and Development in Southern Africa', in K. Matlosa, J. Elklit, and B. Chiroro (eds), Challenges of Conflict, Democracy and Development in Africa, Johannesburg: EISA.

Chikulo, B. C. 2004, 'Local governance and poverty alleviation in South Africa', Regional Development Dialogue, vol. 25, no. 1, pp. 129-146.

Chinsinga, B. 2008, 'Decentralization and Poverty Reduction in Malawi - A Critical Appraisal', in G. Crawford, and C. Hartmann (ed), Decentralization in Africa: A Pathway out of Poverty and Conflict, Amsterdam: Amsterdam University Press.

Christmas, A. and de Visser, J. 2009, 'Bridging the Gap Between Theory and Practice: Reviewing the Functions and Powers of Local Government in South Africa', Commonwealth Journal of Local Governance, vol. 2 (January), pp. 107-119.

Collier, C. 1996, 'NGOs, the Poor and Local Government', Development in Practice, vol. 6, no. 3, pp. 244-249.

de Visser, J. 2009, 'Development Local Government in South Africa: Institutional Fault Lines', Commonwealth Journal of Local Governance, vol. 2 (January), pp. 8-25.

Government of the Kingdom of Swaziland 2005, Local Government Reform and Decentralization (draft), Swaziland: Office of the Deputy Prime Minister.

Government of Lesotho, 2005, Poverty Reduction Strategy 2004/5-2006/2007, Government of Lesotho.

Harrison, P. 2001, 'The Genealogy of South Africa's Integrated Development Plan', Third World Planning Review, vol. 23, no. 2, pp.175-193.

Hofmeister, W. and Scholz, I. 1997, Traditional and Contemporary Forms of Local Participation and Self-Government in Africa. Johannesburg: Konrad-Adenauer-Stiftung.

Hope, K. R. and Chikulo, B. C. 2000, 'Decentralization, the new public management, and the changing role of the public sector in Africa', Public Management, vol. 2, no. 1, pp.25-42. 
Kithakeya, D. 1997, ‘An Overview of Local Government Issues in Various SADC Countries’. Accessed 13 April, 2009 $<$ http://www.thedplg.gov.za/subwebsites/publications/sadcconference/sadcconferencespeech $>$.

Jones, D. 2000, 'Mandela urges traditional leaders to abandon boundary protest', Business Day, 19 September.

Lester, A. Nel, E. and Binns, T. 2000, South Africa ,Past ,Present and Future, Harlow:

Longmans.

Massuangange, I. J. 2006, 'Decentralization and Local Development Programme, 2007-2009', Concept Note to Republic of Mozambique, UNDP \& UNCDF.

Mhlahlo, S. R., 2007, 'Assessment of Urban Governance in Zimbabwe: Case of the City of Gweru’, Eastern African Social Science Research Review, vol. 23, no. 1, pp. 107-128.

Moodley, S. and Sing, D. 1996, 'Local Government Financing in South Africa', in P. S. Reddy (ed), Readings in Local Government Management and Development: A Southern African Perspective, Kenwyn: Juta.

Makumbe, J. 1999, 'Zimbabwe: Decentralisation, development and democracy', in P. S. Reddy (ed), Local Government Democratisation and Decentralisation: A Review of the Southern African Region, Kenwyn: Juta.

Mukwena, R. M. 2004, 'The role of decentralisation in reducing regional inequalities in Namibia', Regional Development Dialogue, vol. 25, no. 1, pp. 108-125.

Mutizwa-Mangisa, N. D. 1990, 'Decentralisation and district development planning in Zimbabwe', Public Administration and Development, vol. 10, no. 4, pp. 423-435.

Ndegwa, S. N. 2002, 'Decentralization in Africa: A Stocktaking Survey', Africa Region Working Paper series, no. 40, World Bank.

Ndiyepa, E. 2001, 'The Role of Traditional Rulers in Namibia’s Decentralization Policy’, Master of Public Policy and Administration Research Paper. Windhoek: University of Namibia.

Nel, E. and Binns, T. 2002, 'Evaluating Local Economic Development Initiatives In South Africa: The Evidence from the Cities', paper presented at the African Studies Association Conference, Birmingham, UK, 11 September.

Ntsebeza, L. 1999, Land Tenure Reform in South Africa: An Example from Eastern Cape, Drylands, issue paper no. 82. London: IIED, 1999.

Olowu, D. and Wunsch, J. S. 2004, Local Governance in Africa: The Challenge of Democratic Decentralization, Lynne Rienner: Boulder.

Oluwu, D., 2001, Decentralization Policies and Practices Under Structural Adjustment and Democratization in Africa, Geneva: UNRISD.

Pycroft, C. 2002, 'Addressing Rural poverty: Resturing Rural Local Government', in S. Pernnell, E. Pieterse, M. Swilling and D. Woolidge (eds), Democratizing Local Government: The South African Experiment, CapeTown University Cape Town Press.

Pycroft, C. 2000a, 'Democracy and delivery: The rationalisation of local government in South Africa', International Review of Administrative Sciences, vol. 66, no. 1. pp.143-159.

Pycroft, C. 2000b, 'Integrated Development planning and Rural Government in South Africa', Third World Planning Review, vol. 22, no. 1, pp. 87-102.

Reddy, P. S. 1999, 'South Africa: Local government, democratisation and decentralisation revisited', in P. S. Reddy (ed), Local Government Democratisation and Decentralisation: A Review of the Southern African Region, Kenwyn: Juta.

Reddy, P. S. and Naidu, R. A. 2007. Traditional Leadership and Local Governance in A Democratic South Africa:"Quo Vadis", Durban: DDP. 
Republic of South Africa 1998, White Paper on Local Government, Pretoria: Department of Constitution Development.

Ribot, J.C. 2004, Waiting for Democracy: The Politics of Choice in Natural Resource Decentralization, Washington, DC: World Resources Institute.

Ribot, J.C. 2002, African Decentralisation: Local Actors, Powers and Accountability, United Nations Research Institute for Social Development Paper No 8. Geneva: UNRISD.

Roe, E. M., 1995, 'More just politics of decentralisation: Local government reform, district development and public administration in Zimbabwe', World Development, vol. 23, no. 5, pp. 833-844.

Sharma, K. C. 2005, 'Local Government For Poverty Reduction in Botswana: An Advance towards good governance in Africa', in R. B. Jain (ed.), Globalization and Good Governance: Lessons for Constructive Reforms, New Delhi: Dup and Deep Publications.

Sharma, K. C. 2003, 'Local government finance and management: A critical factor in the development of local government in Botswana', in P. S. Reddy, D. Sing and S. Moodley (eds), Local Government Financing and Development in Southern Africa, Oxford: Oxford University Press.

Sharma, K. C. 2000, 'Popular participation for good governance and development at the local level', Regional Development Dialogue, vol. 21, no. 1, pp. 177-191.

Smith, R. 2001, 'The duet of decentralisation and unfunded mandates', Journal of Southern African Studies, vol. 27, no. 1, pp.163-183.

Sperfeld, R. 2005, 'Decentralization and Local Government in Lesotho', Government of Lesotho, 2004a, Cabinet: Programme for the Implementation of Local Government in Lesotho. Approved by the Cabinet 10/02/04.

Stewart, F., Klugman, J. and Helmising, A. H. 1994, Decentralisation in Zimbabwe. Accessed on $16^{\text {th }}$ December, $2006<$ http://gd.tuwien.ac.at/soc/undp/oc15.htm>.

Stone, P. 2003, 'Decentralisation in Africa: Goals, dimensions, myths and challenges', Public Administration and Development, vol. 23, no. 1, pp. 7-16.

Tapscott, C. 2000. 'Intergovernmental Relations in South Africa: The Challenges of Co-operative Government', Public Administration and Development, vol. 20, no. 2, pp. 119-127.

Tordoff, W. and Young, A. 1994, 'Decentralisation and Public Sector Reform in Zambia', Journal of Southern African Studies, vol. 20, no. 2, pp. 75-91.

Totemeyer, G. K. H. 2000, 'Decentralisation for empowerment of local units of governance and society: A critical analysis of the Namibian case', Regional Development Dialogue, vol. 21, no. 1.

United Nations 2004, Republic of Mozambique, 2004, Public Administration Country Profile, New York: UNDESA/DPADM.

World Bank 2007, Country Study Angola: Oil, Broad-based Growth and Equity, Washington, DC: World Bank.

Wunsch, J. S. 2001, 'Decentralization, Local Governance and 'Recentralization in Africa', Public Administration and Development, vol. 21, no. 4, pp. 277-288.

Yemek, E. 2005, 'Understanding Fiscal Decentralization in South Africa', IDASA Occasional Papers.

Zambian Government 2002, The National Decentralisation Policy: 'Towards Empowering the People', Lusaka: Office of the President. 